\title{
Vývoj slovenského bryndziarstva a syrárstva do roku 1948 s dôrazom na okres Zvolen
}

\author{
JOZEF PAVLOV \\ Katedra histórie, Filozofická fakulta, Univerzita Mateja Bela \\ v Banskej Bystrici
}

Evolution of the Slovak sheep cheese and cheese industries, until 1948 with an emphasis placed on the Zvolen district

Abstract: The report addresses the evolution of the traditional Slovak sheep cheese and general cheese idustries. It describes the fight of the manufacturers within the battle for (high) quality of sheepe cheese, their professional association in order to coordinate production, distribution and sale of all cheese products. The report highlights the participation of the Zvolen district in this area of the Slovak economy.

Keywords: sheep cheese, cheese, Zvolen district, production, distribution, sale.

DOI: https://doi.org/10.24040/ahn.2020.23.02.210-235

Bryndza je fenoménom slovenského potravinárstva. Jej lokalizáciu na Slovensku zapríčinilo niekol'ko súbežne pôsobiacich faktorov, akými sú valaská kolonizácia, horský a podhorský charakter vel'kej časti slovenského územia, rozšírený chov nenáročných hospodárskych zvierat oviec, laznícka urbanizácia a rol'nícky charakter života vel'kej časti obyvatel'stva. Je nepochybné, že prvú bryndzu - čiže špecifický syr, ako aj iné kvalitatívne odlišné druhy syrov vyrábali bežní l'udia pre vlastnú potrebu už skôr, ako sa oficiálne datuje. S rozvojom všeobecného obchodu a hospodárstva sa však dostávala aj výroba a následná distribúcia týchto komodít na vyššiu kvalitatívnu a kvantitatívnu úroveň.

V súvislosti s týmto procesom zohrali kl'účovú úlohu obchodnícke rodiny z podjavorinského kraja zo Starej Turej. Špeciálne miesto v histórii bryndziarstva a syrárstva má rodina Vagačovcov, a to vd'aka Jánovi Vagačovi (1759 - 1835). Práve on sa udáva v historiografii a v spomienkach ako vynálezca predchodcu dnešnej bryndze. Vagačovcov v obchode a vo výrobe s bryndzou čoskoro nasledovali d'alšie staroturianske rody - napr. Molecovci. Slovensko ako geograficky rozmanitá krajina sa stala vhodným domovom pre tento potravinársky produkt, špeciálne regióny Podpol’anie, Horehronie, Liptov a Spiš. Práve región Podpol'anie a jeho okolie sa stali jadrom slovenského bryndziarstva a syrárstva. Popri rodinách Vagačovcov a Molecovcov sa zlatými pís- 
menami do histórie tohto odvetvia zapísali aj rodiny Wittmannovcov, Blühovcov, Ipperovcov či český mliekarenský odborník Josef Soc.

Charakteristickou črtou vo vývoji mliečneho potravinárskeho priemyslu bolo fungovanie výroby a predaj na báze rodinných podnikov. Takýto druh podnikania sa ukázal ako stály, fungujúci a stabilný. Jednotlivé prevádzky sa líšili osobitnou tradíciou a značkou. Napriek tvrdej konkurencii vládli medzi bryndziarskymi rodinami korektné pracovné a rodinné vzt’ahy.

Turbulentné obdobie rokov 1918 - 1948 zasiahlo významným spôsobom hospodársku stránku jednotlivých podnikov a osobnú históriu bryndziarskych rodín. Rozpad monarchie znamenal zánik obchodných väzieb, zavedenie ciel na export a stratu odbytísk. Krátka okupácia mad'arskou Červenou armádou v júni 1919 spôsobila vel'ké finančné a materiálne škody v kritickom období hospodárskej recesie po roku 1918. Ani obdobie 1. Československej republiky nebolo napriek demokratickému a ekonomicky liberálnemu režimu po hospodárskej stránke bezproblémové. V rokoch 1918 - 1938 zasiahlo československé hospodárstvo niekol'ko cyklicky sa opakujúcich kríz. Prijatie autonómie v októbri 1938 a vyhlásenie štátnej samostatnosti v marci 1939 dali popud rasovým a hospodárskym perzekúciám vplyvného židovského elementu v segmente bryndziarstva a syrárstva. Katastrofické rozmery pre ovčiarstvo, technické zariadenie, dopravné a obchodné prepojenie, personálnu politiku znamenali frontové boje. Krátke intermezzo v rokoch 1945 - 1948 znamenalo isté oživenie, no definitívne pomery v turbulentnom tridsat'ročí uzavrel komunistický prevrat v roku 1948. Ten znamenal radikálnu zmenu hospodárskeho profilu krajiny, ked' otvorenú trhovú ekonomiku nahradilo centrálne riadené hospodárstvo s vylúčením súkromného vlastníctva, a tým pádom vo vel'kej miere aj osobnej angažovanosti. Pozitívom vývoja po roku 1948 bola intenzifikácia a priemyselná modernizácia výroby.

Napriek rôznym t’ažkostiam bolo obdobie rokov 1918 - 1948 aj obdobím progresu, a to vd'aka stabilite rodinných podnikov. Výroba sa skvalitňovala a modernizovala, medzinárodný obchod sa rozvíjal $\mathrm{v}$ riadenej a koordinovanej forme. Ústredným motívom počas skúmaného obdobia bol zápas o kvalitu bryndze, ako aj vytváranie stavovských organizácií na podporu špecifickej legislatívy, výroby, distribúcie a exportu. Pozitívne zmeny však narážali na viaceré objektívne a subjektívne prekážky. Medzi ne patrili prirodzená rivalita, konkurencia a nezhody medzi jednotlivými subjektmi na strane bryndziarov a syrárov. Problematický bol aj postoj vlády, ministerstiev a štátnych úradov, pretože časté personálne zmeny vplyvom nestabilnej politickej scény 1 . ČSR predlžovali riešenie akútnych hospodárskych problémov. 
Podpol’anie a okolie patrili v skúmanom období ku kl'účovej oblasti slovenského bryndziarstva a syrárstva. Na tomto území sa vyrábalo 60 $\%$ z celkového množstva bryndze a syrov pre domáci a zahraničný trh. Medzi tri hlavné podniky patrili Bryndziareň a syráreň Alexander Vagač v Detve, Bryndziareň a syráreň Peter Molec a syn vo Zvolenskej Slatine a Bryndziareň a syráreň Ignác Wittmann a syn vo Zvolene. Dominantné miesto zaujímala v rámci celorepublikového trhu posledná menovaná firma. Tri vel'ké podniky dopíňalo v regióne aj niekol'ko menších prevádzok: Bryndziareň a syráreň Jána Galbavého v Detve, Syráreň Josefa Soca v Dobrej Nive, Bryndziarne a syrárne Kolomana Wittmanna, Gejzu Blüha a Kolomana Ippera vo Zvolene, Rol'nícke mliekarenské družstvo v Detve-Piešti a v Očovej a Syráreň Josefa Lojku v Pliešovciach. Dotazník Zväzu bryndziarskeho a mliekarského priemyslu z roku 1936 spomína aj d'alších menších a dnes už neznámych výrobcov bryndze v regióne: Jakuba Hermanna Weisza z Detvy, Mikuláša Schnellera z Hriňovej, Miloša Pohanku s výrobňami v Pliešovciach a vo Vígl'ašskej Hute-Kalinke, Alžbetu Atlasovú, Gejzu Blüha, Kolomana Ippera a Dezidera Wittmanna zo Zvolena. ${ }^{1}$

Tab. 1. Časové vymedzenie vel'kovýroby bryndze v regióne ${ }^{2}$

\begin{tabular}{|c|c|c|}
\hline LOKALIZÁCIA & MAJITEL & PREVÁDZKA \\
\hline Detva & Alexander Vagač & $1787-1952$ \\
\hline Detva & Ján Galbavý & $1890-1945$ \\
\hline Zvolen & Teodor Wallo & $1892-1917$ \\
\hline Zvolen & Ignác Wittmann & $1891-1951$ \\
\hline Zvolen & Koloman Wittmann & $?-1945$ \\
\hline Zvolenská Slatina & Peter Molec & $1797-$ súčasnost' \\
\hline
\end{tabular}

Tab. 2. Časové vymedzenie vel'kovýroby syrov v regióne ${ }^{3}$

\begin{tabular}{|c|c|c|}
\hline LOKALIZÁCIA & MAJITEL' & PREVÁDZKA \\
\hline Bacúrov & Wittmann a syn & $1919-1947$ \\
\hline Detva & $\begin{array}{c}\text { Alexander Vagač } \\
\text { (prírodné syry) }\end{array}$ & $1917-1952$ \\
\hline
\end{tabular}

\footnotetext{
${ }^{1}$ Slovenský národný archív v Bratislave, fond Zväz bryndziarskeho a mliekarského priemyslu v Banskej Bystrici, šk. č. 1., bez sign.

2 KERESTEŠ, Ján - SELECKÝ, Ján: Mliekarstvo a syrárstvo na strednom Slovensku. Považská Bystrica : Eminent, 2003, s. 199 - 202.

3 KERESTEŠ, J. - SELECKÝ, J.: Mliekarstvo a syrárstvo ..., s. 199 - 202. 
Vývoj slovenského bryndziarstva a syrárstva do roku 1948 ...

\begin{tabular}{|c|c|c|}
\hline Detva & $\begin{array}{c}\text { Alexander Vagač } \\
\text { (tavené syry) }\end{array}$ & $1932-1952$ \\
\hline Detva & Ján Galbavý & $1931-1945$ \\
\hline Dobrá Niva & J. Soc/Gabriela Socová & $1932-1947$ \\
\hline Očová & Rolnícke družstvo & $1920-1945$ \\
\hline Pliešovce & J. Soc, Josef Lojka & $1923-1945$ \\
\hline Sása & Rol'nícke družstvo & $1920-1951$ \\
\hline Vígl'aš-Pstruša & Burkhard & $1896-1910$ \\
\hline Vígl'aš-Pstruša & Správa štátnych majetkov & $1924-1942$ \\
\hline Zvolen & Wittmann a syn & $1891-1948$ \\
\hline Zvolenská Slatina & $\begin{array}{c}\text { Peter Molec } \\
\text { (tavené syry) }\end{array}$ & $1928-1951$ \\
\hline
\end{tabular}

Z heuristického hl'adiska je oblast' bryndziarstva a syrárstva na Slovensku spracovaná $\mathrm{v}$ dvoch významových líniách: $v$ prvej je predmetom výskumu bryndza a syr ako potravinársky produkt, v druhej je predmetom výskumu bryndziarstvo a syrárstvo ako druh potravinárskeho priemyslu v určitom časovom úseku. Hlavným predstavitel'om prvého prístupu je dejepisec mliekarenstva a mliekarenský technológ Ján Selecký. Jeho tri hlavné práce Slovenské syry, Slovenská bryndza a jedlá s bryndzou a Mliekarstvo a syrárstvo na strednom Slovensku sa zameriavajú skôr na biochemickú stránku bryndziarstva a syrárstva, pričom historický kontext je len doplňujúci a parafrázujúci existujúce práce, zdroje a štúdie bez významného vedeckého prínosu. Druhý prístup reprezentuje málopočetný, ale pestrý fragment zdrojov, ktorý delíme na samostatné štúdie a publikácie. Medzi štúdie zarad'ujeme prácu Aleny Bartlovej Kdejinám potravinárskeho priemyslu na Slovensku v rokoch 1918 - 1938 a štúdie Juraja Janta Slovenské bryndziarstvo a vagačovská výrobňa v Detve a Salašný chov oviec v Detve a na Slovensku. Medzi základné písomné a publikované pramene môžeme zaradit’ brožúru $k$ 150. výročiu Vagačovej bryndziarne, ktorú zostavil na objednávku Štefana Vagača Gustáv Hladil a odbornú publikáciu tajomníka banskobystrickej Obchodnej a priemyselnej komory, poslanca Snemu Slovenskej republiky a člena Štátnej rady Jána Balka - Bryndziarsky priemysel na Slovensku. Fragmenty z histórie bryndziarstva a syrárstva sú aj v lokálnych monografiách obcí, no obsahujú len málo podnetné informácie. Ciel'om štúdie je na základe podrobného archívneho výskumu a vhodným spracovaním overených faktov z existujúcich publikovaných prameňov vytvorit' obraz vývoja bryndziarstva a syrárstva s dôrazom na roky 1918 - 1948 a región Podpol'ania a okolia. Nosným zdrojom 
prameňov predloženej štúdie sú písomné pramene uložené vo viacerých fondoch niekol'kých archívov. Kl'účovými pre výskum sa ukázali najmä dva fondy: fond Okresný úrad vo Zvolene 1923 - 1945 uložený v Štátnom archíve v Banskej Bystrici, pracovisko Archív Zvolen a fond Bryndziarskeho a syrárskeho priemyslu uložený v Slovenskom národnom archíve v Bratislave.

\section{Zápas o kvalitu bryndze}

Výroba bryndze zaznamenala koncom 19. storočia vel'ké zmeny vd'aka Teodorovi Wallovi zo Zvolena. Snažil sa o štandardizáciu kvality ovčieho hrudkovitého syra a aktívne skúmal výrobu mäkkej a roztieratel'nej bryndze. ${ }^{4}$ Zmena výroby podl'a T. Walla spočívala v tom, že „pridal namiesto tuhej soli do rozdrveného syra osobitne pripravený sol'ný roztok. Získal tak mäkkú a roztieratel'nú bryndzu, ktorá sa s menšími úpravami vyrába dodnes. Objavenie a uvedenie mäkkej roztieratel'nej bryndze v roku 1892 a jej balenie v geletách viedlo k novej etape jej výroby a k rastúcemu záujmu. “5 Pri dovážaní Wallovej bryndze do exportných odbytíšt' sa ukázal vážny problém, ked' bryndza uvol'ňovala vodu a presakovala na povrch prepravných súdkov. To spôsobovalo jej rýchlejšie kazenie. „Vystielaním súdkov bukovou dýhou zvanou dračkou sa docielilo, že uvol'nenú vodu z povrchu bryndze dračka odsávala, odovzdávala vonkajšiemu obalu, ktorý ju postupne odovzdával odparením do ovzdušia."6

Výrazný prepad v kvalite bryndze nastal po roku 1914, a to z dôvodu, že „po vypuknutí vojny vzrástol odbyt bryndze v súvislosti so zásobovaním armády a nedostatkom potravín v zázemí."7 Práve v tomto období začali rôzni špekulatívni obchodníci vo vel'kom vyrábat' syr nízkej kvality a predávali ho pod názvom bryndza. $V$ čase zápasu o kvalitu bryndze sa poctiví bryndziari zo zvolenského regiónu usilovali o zvrátenie tohto stavu, preto zjednotili sily a v roku 1917 založili Hornouhorské spojené bryndziarne Zvolen. Do tohto podniku patrili bryndziarne Molec Zvolenská Slatina, Vagač Detva, Blüh Zvolen a Wittmann Zvolen. „Najaktívnejší presadzovatel' ozdravenia výroby hrudkovitých syrov z bryndze Teodor Wallo ${ }^{8}$ 17. mája 1917 zatvoril svoju

\footnotetext{
${ }^{4}$ SELECKÝ, Ján: Slovenské syry. Bratislava : Eko-konzult, 2013, s. 172.

${ }^{5}$ JANTO, Juraj: Slovenské bryndziarstvo a vagačovská výrobňa v Detve. K 230 . výročiu vzniku prvej bryndziarne. In: Muzeológia a kultúrne dedičstvo. roč. 5, č. 2, 2017, s. 55.

${ }^{6}$ SELECKÝ, J.: Slovenské syry..., s. 285.

${ }^{7}$ BARTLOVÁ, Alena: K dejinám potravinárskeho priemyslu na Slovensku v rokoch 1918 1938. In: Túžby, projekty a realita. Zost. A. Bartlová. Bratislava : Prodama, 2010, s. 152.

8 Teodor Wallo (1861 - 1932): Študoval v Starej Turej, v Banskej Bystrici a v Budapešti. Od roku 1881 pôsobil v podniku svojho otca vo Zvolene. Bol majitel'om niekol'kých medailí zo zahraničných výstav, kde propagoval svoju bryndzu. Angažoval sa v politike - bol senátorom za SL'S, medzi jeho zál'uby patrilo pol'ovníctvo. (RUMÁNEK, Gustáv: 
bryndziareň $v$ dôsledku toho, lebo vláda v Budapešti neriešila ozdravenie výroby syra a bryndze." ${ }^{9}$ Podl'a iného zdroja boli súčast'ou tohto podniku aj istý A. Vagó, F. Molnár, M. Deckner, E. Endre, A. Finka, ${ }^{10} \mathrm{~J}$. N. Walló a L. Sebes. ${ }^{11}$

Vplyvom vojnových pomerov vyrábali Hornouhorské spojené bryndziarne do roku 1919 len bryndzu. Postupne bola výroba rozširovaná. Dôležitým krokom vedenia spojeného podniku bolo angažovanie dvoch mliekarenských odborníkov - bývalého riaditel'a mliekarenskej školy v Kroměříži Josefa Líšku a jeho žiaka Josefa Soca. Ich výrobným programom bolo oživenie výroby plesňového syra, nadväzujúc na burkhardovskú tradíciu na Masarykovom dvore. ${ }^{12}$ Po obnovení výroby tohto produktu sa zavádza výroba aj d'alších druhov syrov. ${ }^{13}$ Podnik vlastnil a prevádzkoval pobočky v Bacúrove, v Čereňoch, v Detve, v Dobrej Nive, v Radnovciach, v Šarluhách, vo Vel'kej Lúke, v Očovej, vo Zvolene a vo Zvolenskej Slatine. „V roku $1923^{14}$ Spojené bryndziarne zanikajú pre finančné rozpory medzi podielnikmi. Príčinou je pravdepodobne rast kapitálového podielu I. Wittmanna." 15 Túto verziu potvrdzuje aj G. Blüh, ked' tvrdí, že zo spoločných obchodov si najväčší zisk delil I. Wittmann, napriek nižšiemu podielu k pomeru k výrobe. ${ }^{16}$

Spojené bryndziarne sa často chápu ako jeden podnik, no v skutočnosti vyrábali všetky súčasti spolku bryndzu samostatne, len ju predávali pod spoločným názvom garantujúcim kvalitu suroviny a výroby. ${ }^{17}$ Jednotlivé časti bryndziarskeho vel'kopodniku fungovali v d'alších rokoch už ako nezávislé subjekty. Bryndziari a syrári postupne modernizovali svoje výrobné základne, rozširovali sortiment, zvyšovali zamestnanost' v regióne a export svojich výrobkov. Ked'že v malom regióne pôsobilo niekol'ko podobných podnikov, vytváral sa silný tlak na potrebu stálosti dodávatel'ov. Medzi bryndziarmi existovala dohoda, na základe ktorej mali pri výkupe mlieka rozdelený región na rajóny - obvo-

Trvalky - otvorený súbor 173 životopisov nežijúcich osobností. Stará Turá : T-štúdio, 2016, s. 162).

${ }^{9}$ SELECKÝ, Ján: Slovenská bryndza a jedlá s bryndzou. Zvolen : Vlastným nákladom autora, 2008, s. 62.

10 Alexander Finka bol významným zvolenským vel'kostatkárom, pôvodom zo Sv. Kríža nad Hronom (dnešný Žiar nad Hronom).

${ }^{11}$ BARTLOVÁ, A.: K dejinám potravinárskeho priemyslu..., s. 152.

12 Neformálne pomenovanie statku vo Vígl'aši-Pstruši.

13 Trapist, salám, eidam, tylžský a ementál.

${ }^{14}$ Jozef Soc vo svojej štúdii o mliekarstve uvádza ako rok rozpadu Spojených bryndziarní rok 1922. SOC, Josef: Mlekarstvo na Slovensku. In: Stredné Slovensko. Zvolen : Národohospodárska župa stredoslovenská, 1934, s. 78.

1525 rokov mliekarenského závodu vo Zvolene 1951 - 1976, s. 38. (brožúra).

${ }^{16}$ SNA BA, f. Zv a MP v BB, šk. č. 3, bez sign.

${ }^{17}$ BARTLOVÁ, A.: K dejinám potravinárskeho priemyslu..., s. 152. 
dy. Väčšina rešpektovala tieto dohody. ${ }^{18}$ Bližšie problémy a spory opisuje bryndziar G. Blüh: „Nekalé spôsoby praktizovali niektorí bryndziari pri nákupe surového hrudkového syra. Dávali vel'ké preddavky na ovce a na syr, či zaplatili také nemožné ceny, ktoré boli skoro nerentabilné. Často dávali dodávatel'om oldomáše a či sami sa s dodávatel'mi zabávali pri nápojoch a alkohole. Podobné neblahé zákroky zapríčinili, že len niektorí bryndziari získali dodávatel'ov kvalitného hrudkového ovčieho syra."19

Tab. 3. Výkup ovčieho hrudkového syra určený Bryndziarskym syndikátom pre rok 1936

\begin{tabular}{|c|c|c|c|c|}
\hline OKRES & ZVOLEN & LUČENEC & MARTIN & $\begin{array}{c}\text { LIP. } \\
\text { MIKULÁŠ }\end{array}$ \\
\hline KG & 471835 & 154628 & 117967 & 88691 \\
\hline
\end{tabular}

Zápas o kvalitu bryndze pretrvával nad'alej. Stimulátorom týchto aktivít boli mnohí obchodníci a špekulanti, ktorí za cenu zmaximalizovania ziskov nad'alej znižovali kvalitu bryndze rôznymi spôsobmi. Najčastejšie ovčí syr ako základnú surovinu na výrobu bryndze nahrádzali lacnejším kravským. Do bryndze taktiež primiešavali margarín či zemiaky. „Stav bryndziarskej výroby bol už natol'ko zhumpl'ovaný, že už skoro každý obchodník s miešaným tovarom mlel na malom mlynčeku kravský tvaroh s margarínom a predával tento výrobok ako bryndzu. "20

Od počiatku 1. Československej republiky boli vyvíjané snahy o legislatívne zastrešenie výroby bryndze. „V roku 1927 bolo prijaté vládne nariadenie o výrobe hrudkového syra a bryndze a ich predaji. Bola to prvá legislatívna úprava slovenskej bryndze. Nariadenie vymedzilo pojem syra a bryndze a zaviedlo akostné označenie na obaloch."21 Autorom tohto nariadenia bol L'udevít Tejkal, inšpektor mliekarenstva v Bratislave. V praxi však tento zákon vel'a nepomohol. Jednou z prvých národných organizácií, ktoré mali na zreteli pozdvihnutie slovenského bryndziarstva bola Mliekarenská jednota na Slovensku. Úspechom tejto organizácie bolo presadenie zníženia prepravných taríf na mliečne výrobky v roku $1922 .{ }^{22}$ Cestu preklenutia problémov videli bryndziari v užšej integrácii v rámci svojej špecifickej výroby. V roku 1934 bola pod vedením zvolensko-slatinského bryndziara Petra Moleca utvorená

\footnotetext{
${ }^{18} 200$. výročie bryndziarne vo Zvolenskej Slatine (brožúra).

${ }^{19}$ SNA BA, f. ZB a MP v BB, šk. č. 3, bez sign.

${ }^{20}$ BALKO, Ján: Bryndziarsky priemysel na Slovensku. Martin : Družstvo pre predaj bryndze, 1940, s. 29.

${ }^{21}$ BALKO, J.: Bryndziarsky priemysel...., s. 33.

${ }^{22}$ BARTLOVÁ, A.: K dejinám potravinárskeho priemyslu..., s. 152.
} 
Vývoj slovenského bryndziarstva a syrárstva do roku 1948 ...

komisia, ${ }^{23}$ ktorá mala „sústredit' pripomienky k návrhu kartelovej zmluvy za účelom uzdravenia obchodu s bryndzou a regulovania jej výroby a predaja."24 Výsledkom týchto snáh bolo zriadenie Bryndziarskeho syndikátu $^{25}$ a o niečo neskôr Zväzu bryndziarskeho a mliekarského priemyslu pre Slovensko26 so sídlom v Banskej Bystrici. Predpokladom vzniku Bryndziarskeho syndikátu boli rôzne úvahy, diskusie a konferencie o reštartovaní slovenského hospodárstva po období hospodárskej krízy. Základným impulzom však bolo schválenie kartelového zákona č. $141 / 1933$. Jeho význam spočíval v tom, že „sa stal významným podnetom na d'alšie združovanie priemyselných podnikov, dokonca tiež na nútenú tzv. syndikalizáciu niektorých predtým nekartelovaných priemyselných odvetví československej ekonomiky." 27 Činnost' Bryndziarskeho syndikátu začala naplno až v roku 1936. V rámci svojich kompetencií určoval pravidlá a hranice výkupu ovčieho hrudkového syra, určoval výkupné a predajné ceny, dozeral na kvalitu základnej suroviny na výrobu bryndze, rovnako aj na kvalitu spracovania vo výsledku konečného produktu pre spotrebitel'a, snažil sa o pozitívne ovplyvnenie platnej legislatívny, daňové úl'avy a ekonomické výhody chovatel'ov oviec a bryndziarov. Hlavným ciel'om však bolo „likvidovat' vzájomný konkurenčný zápas medzi bryndziarmi, ale súčasne aj zamedzit' vytváraniu d'alších bryndziarskych prevádzok."28

Štruktúra vedenia Bryndziarskeho syndikátu bola zložená z nominantov navrhnutých Zväzom chovatel'ov oviec a nominantov navrhnutých Ministerstvom priemyslu, obchodu a živností podl'a návrhu Obchodnej a priemyselnej komory v Banskej Bystrici. Najužšie vedenie malo osem členov, štyria patrili k chovatel'om oviec a štyria k výrobcom bryndze. Vo vedení boli dvaja bryndziari zo zvolenského okresu, a to Š. Vagač29 a P. Molec. Celkovo do štruktúr syndikátu vstúpilo 48 výrobcov. Ustanovujúca schôdza druhej stavovskej organizácie - Zväzu bryn-

\footnotetext{
${ }^{23}$ Jej členmi boli d’alší známi bryndziari - Josef Soc, Vladimír Lajda, Grosswirth, Buchta a Stark.

${ }^{24}$ SNA BA, f. ZB a MP v BB, šk. č. 1, bez sign.

25 „Po dlhých priet'ahoch predložilo Ministerstvo pol'nohospodárstva návrh na zriadenie Bryndziarskeho syndikátu ministerskej rade, ktorá ho prerokovala a schválila 13. 7. 1935. Ministerská rada prijala a odsúhlasila v ten deň vládne nariadenie č. 159/1935 o výrobe a speňažení hrudkového syra a bryndze a vládne nariadenie č. 160/1935 o zriadení Bryndziarskeho syndikátu. "BARTLOVÁ, A.: K dejinám potravinárskeho priemyslu..., s. 162 - 163. ${ }^{26}$ Zväz mal tri sekcie: pre bryndziarstvo, pre syrárstvo a pre mliekarstvo.

${ }^{27}$ BARTLOVÁ, A.: K dejinám potravinárskeho priemyslu..., s. 159.

${ }^{28}$ BARTLOVÁ, A.: K dejinám potravinárskeho priemyslu..., s. 161.

${ }^{29}$ Alena Bartlová uvádza meno A. Vagač, avšak Alexander zomrel v roku 1934, pričom jeho podnik prebral jeho prvorodený syn Štefan. Často sa stávalo na dokumentoch, že bolo uvádzané oficiálne meno bryndziarne A. Vagač, a tak došlo v kontexte k nesprávnej interpretácii mien Alexander a Štefan.
} 
dziarskeho a mliekarského priemyslu sa konala v Rol'níckom dome v Turčianskom sv. Martine 26. novembra 1935, riadnu činnost' začala organizácia vykonávat' od 1. decembra 1935. Predseda Obchodnej a priemyselnej komory ${ }^{30} \mathrm{v}$ Banskej Bystrici Václav Waschko na tomto zhromaždení apeloval na bryndziarov: „dnešné pomery v obore bryndziarstva, syrárstva a mliekarstva, jedno či ide o družstevné alebo súkromné podniky, presviedča nás o nutnosti spoločnej a jednotnej organizácie pre Slovensko, v ktorej by boli zastúpení všetci tí, ktorí majú $k$ mliekarenskej výrobe akýkol'vek vzt'ah. Len taká organizácia, ktorá sústredí všetky zložky mliekarenského priemyslu, môže byt' silnou, aby jej záujmy boli rešpektované a jej oprávnené požiadavky uplatnené." ${ }^{31}$ Zriadenie Zväzu bolo dôležitým evolučným a integračným momentom bryndziarskeho a syrárskeho priemyslu na Slovensku. Pre vstup do Zväzu boli určené prísne kritériá, ako napr. tradícia a objem výroby, množstvo exportu, počet zamestnancov a pod. Za predsedu bol zvolený predseda OaPK v Banskej Bystrici V. Waschko, sekretárom sa stal na návrh P. Moleca tajomník komory, dr. Ján Balko. Smerovanie organizácie určoval výbor volený na jeden rok, ktorý pozostával z desiatich členov. Ich zloženie muselo byt' založené na geografickom základe, jedno stále miesto bolo určené pre zástupcu Zväzu chovatel'ov oviec. Financovanie organizácie bolo založené na podieloch a ročných členských príspevkoch, ktoré sa určovali podl'a výkonnosti členských podnikov. V rámci stanov organizácie sa určil ako hlavný záujem a ciel' „snaha kartelu, aby ceny bryndze boli stabilizované a znemožnená bola nekalá konkurencia." ${ }^{32}$ Zaujímavost'ou bolo, že „členstvo v karteli je nútené a vystúpit' je možné len tak, že by sa príslušná firma vzdala výroby bryndze. “33 Tento fakt dokazuje, že v polovici 30. rokov 20. storočia bola situácia v bryndziarskom priemysle vážna. Aj preto sa členmi stali všetky významné bryndziarske a syrárske podniky z okresu Zvolen. ${ }^{34}$ Boli to sami bryndziari, ktorí iniciovali vznik kartelovej organizácie a deklarovali spoločný postup, často však medzi nimi zvít’azili egoistické pohnútky. Tvrdá kritika od predsedu Zväzu voči nim bola prednesená na valnom zhromaždení35

\footnotetext{
${ }^{30}$ Ďalej OaPK.

${ }^{31}$ SNA BA, f. ZB a MP v BB, šk. č. 1, bez sign.

${ }^{32}$ SNA BA, f. ZB a MP v BB, šk. č. 1, bez sign.

${ }^{33}$ SNA BA, f. ZB a MP v BB, šk. č. 1, bez sign.

${ }^{34}$ Bryndziareň a syráreň A. Vagač a Bryndziareň a syráreň J. Galbavý z Detvy, Mliekarenský podnik Josefa Soca z Dobrej Nivy, Bryndziareň a syráreň I. Wittmann a syn, bryndziarne K. Wittmanna, K. Ippera, G. Blüha zo Zvolena a Bryndziareň a syráreň P. Moleca zo Zvolenskej Slatiny. Zároveň uvedení bryndziari obsadili v novej organizácii významné funkcionárske posty: za podpredsedu bol zvolený V. Wittmann, Š. Vagač sa stal pokladníkom. (SNA BA, f. ZB a MP v BB, šk. č. 3, bez sign.).

${ }^{35}$ Hodnotilo obdobie od 1. decembra 1935 do 31. decembra 1936.
} 
organizácie konanej 11. mája 1937, ked’ konštatoval, že „Zväz vo väčšine nepochopilo ani vlastné členstvo." ${ }^{36}$ Vo svojom prejave kritizoval vzájomné škriepky, nekalú konkurenciu, dokonca ignorovanie povinnosti platit' členské. Na záver ich vyzval, aby sa vyjadrili, či chcú, alebo nechcú nad'alej fungovanie Zväzu. ${ }^{37} \mathrm{~V}$. Waschko zdôraznil pomoc jeho domovskej organizácie - OaPK na podporu Zväzu, ked' poskytla bezodplatne vlastné priestory pre Zväz, hradila energie na chod kancelárie, účty za telefón a pod. Počas valného zhromaždenia sa rokovalo aj o organizačných zmenách, ked’že mliekarne sa rozhodli vystúpit' z kartelových štruktúr. Organizácia bola pretransformovaná na Zväz bryndziarskeho a syrárskeho priemyslu. ${ }^{38}$ Valné zhromaždenie za rok 1937 opät' hodnotilo spoluprácu kriticky, ${ }^{39}$ najmä v rovine zlej komunikácie, stáleho nepochopenia významu Zväzu a neplatenia členského. ${ }^{40}$ Zaujímavost'ou rokovania bolo rezolútne odmietnutie brožúry o budúcnosti bryndziarstva od V. Wittmanna. Jeho podnik už v roku 1936 opustil štruktúry Zväzu a nevraživost' medzi členmi voči jeho podniku bola zretel'ná. Prijaté uznesenie hovorilo, že „väčšina členstva Zväzu zaujíma k brožúre kritické a odmietavé stanovisko." ${ }^{1}$ Proces hlbšej integrácie a spolupráce však pokračoval. Na návrh Zväzu a OaPK v Banskej Bystrici počas schôdze 23. mája 1938 bolo zriadené Družstvo pre predaj bryndze a iných mliekarenských výrobkov so sídlom v Žiline. ${ }^{42}$ Už na februárovej schôdzi za jeho vytvorenie hlasovalo 32 zo 40 členov. V komisii ohl'adne jeho vytvorenia nechýbali ani regionálni bryndziari G. Blüh, P. Molec, Š. Vagač a Koloman Wittmann. Všetci obsadili v Družstve dôležité funkcionárske posty.

Na valnom zhromaždení Zväzu v januári 1939 sa viedla búrlivá diskusia o tom, či majú existovat' dve podobné stavovské organizácie. ${ }^{43}$ Predseda Zväzu V. Waschko bol rezolútne za fungovanie oboch organizácií: „Založením družstva zdá sa, že činnost' Zväzu pozbýva svojho význa-

\footnotetext{
${ }^{36}$ SNA BA, f. ZB a MP v BB, šk. č. 3, bez sign.

37 Počas prvého roku svojej činnosti Zväz vybavil 78 tel. hovorov, intervenoval v 150 prípadoch, vybavil 136 stránok, zorganizoval dve schôdze predsedníctva, jednu schôdzu výboru, štyri členské schôdze a zorganizoval aj dve stretnutia vývozcov bryndze do Rakúska. (SNA BA, f. ZB a MP v BB, šk. č. 3, bez sign.)

${ }^{38}$ SNA BA, f. ZB a MP v BB, šk. č. 3.

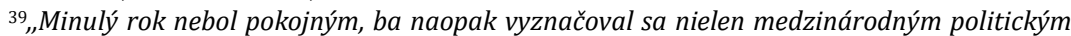
chaosom, ale aj hospodárskym nepokojom. Časy sú zlé vážení pánovia, a my si nemôžeme dovolit' luxus neriadenej konkurencie a vlastného nivočenia sa. Preto uznáte, že je už raz treba urobit' poriadok a základným kameňom tohto poriadku ak ho chceme, je utvorenie Družstva pre predaj bryndze." (SNA BA, f. ZB a MP vBB, šk. č. 3, bez sign.)

${ }^{40}$ SNA BA, f. ZB a MP v BB, šk. č. 3, bez sign.

${ }^{41}$ SNA BA, f. ZB a MP v BB, šk. č. 3, bez sign.

4225 rokov mliekarenského závodu vo Zvolene 1951 - 1976, s. 54. (brožúra).

${ }^{43}$ Myslené - Zväz aj Družstvo.
} 
mu, ked' máme na mysli iba hospodársky záujem členov. Inakšie však vec vyzerá, ked' vezmeme do úvahy momenty verejno-právnej povahy, kedy je udržat' si Zväz nielen účelným, ale aj nutným, lebo výrobcovia bryndze musia mat' nielen svoju distribučnú organizáciu, ale i riadnu organizačnoprávnej povahy." 44 Obdobie 1 . SR znamenalo pre bryndziarstvo a syrárstvo d'alšie zmeny. V zmysle štátnej protižidovskej hospodárskej a rasovej politiky bol židovský element vo výrobe a predaji bryndze a syrov zlikvidovaný, a to dvoma spôsobmi: výnosné podniky boli arizované, t. j. prešli do vlastníctva Árijcov (často však neodborníkov, čo malo zlý vplyv na chod arizovaného podniku) alebo boli jednoducho zrušené. Toto malo za následok pokles celkovej výroby a predaja, no slovenským a krest'anským obchodníkom to znížilo konkurenciu na trhu. To sa však prejavilo $\mathrm{v}$ určitom poklese kvality výrobkov. Ministerstvo hospodárstva ${ }^{45}$ vedené Gejzom Medrickým pripravovalo vel'kú centralizáciu výroby, za účelom ktorej v roku 1941 vznikol štátom podporovaný Zväz mliekarenských družstiev so sídlom v Bratislave. Jeho základom sa stali arizované podniky a menšie prevádzky, ktoré boli nerentabilné. Štát plánoval miliónové investície do jeho budovania, ale vojnové pomery proces centralizácie a modernizácie výroby zabrzdili a v konečnom dôsledku znemožnili. Pre celý segment bolo však vel'mi výhodné to, že tajomník OaPK J. Balko sa stal členom Štátnej rady a poslancom Slovenského snemu a otázku bryndziarstva a syrárstva dostával pravidelne do popredia.

Vojnové pomery a prechod frontu významne narušili obchodné väzby a spôsobili d'alekosiahle deštrukcie. Ešte v roku 1947 výkup mlieka na d'alšie spracovanie nedosahoval ani 50 \% úrovne z roku 1941.46 Továrnik a bryndziarsky odborník V. Wittmann vypracoval v roku 1947 pre zborník hospodárskych problémov stredného Slovenska štúdiu o problémoch mliekarenstva v regióne. V nej ozrejmuje podmienky, v akých sa mliekarenský sektor nachádzal, aké mal vlastnícke pozadie, priestorové a výrobné rozloženie podnikov. Poukazoval aj na vedúcu úlohu Národohospodárskej župy Stredoslovenskej v mliekarenstve, ked’ uvádzal, že sa tu nachádza $75 \%$ taviarní, 69,2\% mliekarenských podnikov a 55,5\% bryndziarní: „v tejto oblasti je t’ažisko mliekarenského priemyslu na Slovensku a jeho stred spadá do okresu Zvolen." ${ }^{47}$ D̆alej V. Wittmann pouká-

\footnotetext{
${ }^{44}$ SNA BA, f. ZB a MP v BB, šk. č. 3, bez sign.

45 Pre obraz hospodárskej politiky počas 1 . SR odporúčame napr. MEDRICKÝ, Gejza: V práci za povznesenie národa. Bratislava : Post Scriptum, 2017 alebo MIČKO, Peter: Hospodárska politika slovenského štátu. 2. vydanie, Krakov: Spolok Slovákov v Pol'sku, 2014.

46 Tak napríklad vo Zvolene nedosahoval výkup ani 900 tisíc l. Vo Zvolenskej Slatine to bolo 205658 l a v Detve, v rámci podnikov Ing. Š. Vagača a Š. Galbavého, $136527 \mathrm{l}$.

47 WITTMANN, Vojtech: Problémy mliekarenstva na strednom Slovensku. In: Zborník hospodárskych problémov stredného Slovenska. Zvolen : Národohospodárska župa stredoslovenská, 1947, s. 136.
} 
zal na to, že na území obsadenom Mad'armi v rokoch 1938 - 1945 výroba stagnovala a nik ju nepodporoval. 0 nič lepšie podmienky podl'a jeho mienky neboli ani na Slovensku. Udával, že jedenást' podnikov bolo v rokoch 1939 - 1945 zlikvidovaných a v dvanástich sa výroba dosial' neobnovila. Vel'ké škody celoplošne spôsobil aj prechod frontu. Problémy sa vyskytovali tak v nedostatku výkupu mlieka, ako aj v jeho kvalite. „Podniky sú v dôsledku nedostatočného príjmu mlieka nútené uvádzat’ všetko mlieko do konzumu a len z rozdielu tučnosti vyrábajú mizivé percentá masla. Výroba syrov neprichodí v úvahu. Regulovaný trh trpí nedostatkom mlieka. Konzum je nútený vyhl'adávat' trh neregulovaný a do zásobovania mliekom i mliečnymi výrobkami vnáša sa chaos." ${ }^{48}$

Definitívny koniec súkromného bryndziarstva a syrárstva znamenal komunistický prevrat vo februári v roku 1948, prechod na plánované hospodárstvo, emigrácia a perzekúcia niektorých bryndziarskych rodín.

\section{Export bryndze a syrov, charakteristika dobového ovčiarstva}

Ústrednou otázkou syrárstva a bryndziarstva bol odbyt a export. V minulosti bola bryndza prepravovaná na pltiach po toku Váhu, konskými povozmi a od druhej polovice 19. storočia železnicou. Problematická však bola hlavne jej trvanlivost'. Rokmi sa expedícia a dlhšia doba spotreby zlepšili.

Prvým negatívom pre pôsobenie bryndziarstva a export výrobkov bol rozpad Rakúsko-Uhorskej monarchie. „Pred prvou svetovou vojnou dodával užší okruh tradičných najvýznamnejších slovenských bryndziarskych závodov bryndzu do všetkých oblastí monarchie." ${ }^{49}$ Treba brat' do úvahy, že išlo o trh pre 52 miliónov obyvatel'ov. Nové domáce prostredie 1 . ČSR s vyše 14 miliónmi obyvatel'ov nedokázalo stratené trhy a odbyt nahradit'. Navyše, musíme poukázat' aj na fakt, že minimálne na slovenskom území si väčšina rol'níkov vedela sama dorobit' syry a bryndzu rôznej kvality. Z hl'adiska mestského obyvatel'stva ako potenciálni odberatelia pripadali vhod len príslušníci malomeštiactva, úradníctva a podnikatel'ov, ked’že sociálna väčšina - robotníctvo, malo len slabú kúpnu silu.

V rámci povojnového exportu boli „najt'ažšou prekážkou predaja bryndze novovytvorené hranice a colné bariéry medzi nástupníckymi štátmi. Susedné krajiny sa snažili stat'sa samostatnými v zásobovaní vnútorného trhu. Začali si budovat' rozsiahlu siet' mliekarenských závodov." ${ }^{50}$

Ďalším úderom pre export bryndze bolo vypuknutie hospodárskej krízy, a to hned' dvakrát. Najprv vplyvom povojnovej konverzie zo za-

\footnotetext{
${ }^{48}$ WITTMANN, V.: Problémy mliekarenstva..., s. 136.

${ }^{49}$ BARTLOVÁ, A.: K dejinám potravinárskeho priemyslu..., s. 152.

${ }^{50}$ BARTLOVÁ, A.: K dejinám potravinárskeho priemyslu..., s. 153.
} 
čiatku 20. rokov a neskôr po roku 1929 vplyvom globálnej hospodárskej krízy. Kým v roku 1918 sa do Rakúska ${ }^{51}$ ako najväčšieho exportného odbytištia vyvážalo zo Slovenska ročne 90 - 95 vagónov bryndze, v roku 1933 to bolo len 42 vagónov. ${ }^{52}$ Výrazný pokles bol zaznamenaný aj v rámci d’alších štátov, najmä susedných. ${ }^{53}$

Bližšie údaje o konkrétnom množstve vyvezenej bryndze $\mathrm{z}$ regionálnych podnikov máme z roku 1935, ked' sa konštituoval Zväz bryndziarskeho a mliekarského priemyslu. Práve podl'a vel'kosti kontingentov exportu do zahraničia sa určovali členské príspevky v stavovskej organizácii. ${ }^{54}$

Tab. 4. Export bryndze v tonách/vagónoch do zahraničia ${ }^{55}$

\begin{tabular}{|c|c|}
\hline MAJITEL' PODNIKU & EXPORT V TONÁCH \\
\hline Gejza Blüh - Zvolen & $40 / 4$ \\
\hline Ján Galbavý - Detva & $20 / 2$ \\
\hline Koloman Ipper - Zvolen & $20 / 2$ \\
\hline Peter Molec - Zvolenská Slatina & $90 / 9$ \\
\hline Jozef Soc - Dobrá Niva & neexpedoval \\
\hline Štefan Vagač - Detva & $10 / 1$ \\
\hline Dezider Wittmann - Zvolen & neexpedoval \\
\hline Vojtech Wittmann - Zvolen & $170 / 17$ \\
\hline Koloman Wittmann - Zvolen & $45 / 4,5$ \\
\hline
\end{tabular}

Export bryndze bol pod vel'kým tlakom, čo spôsobovalo znižujúci sa dopyt po tomto špecifickom mliečnom výrobku. Mnohí obchodníci predávali pod cenu, aby vyexpedovali skladové zásoby, čím deformovali trh. Neexistovala žiadna forma štátnej podpory ako v okolitých štátoch, viazol spoločný marketing predaja. Ako vel'mi vážny problém vnímali bryndziari rast mad'arskej konkurencie na rakúskom trhu, ktorý bol pre export kl'účový. Postupne sa mad'arská bryndza dostala na $20 \%$ trhový podiel. Vel'kým plusom pre mad'arských výrobcov boli dotácie,

\footnotetext{
${ }^{51}$ Pravdepodobne je myslená celá rakúska čast' monarchie, tzv. Predlitavsko.

52 Pôvodne 1500 ton, neskôr 530 ton. (BARTLOVÁ, A.: K dejinám potravinárskeho priemyslu..., s. 153.)

5325 rokov mliekarenského závodu vo Zvolene 1951 - 1976, s. 58. (brožúra)

${ }^{54}$ Zväz bryndziarskeho a syrárskeho priemyslu, Bryndziarsky syndikát pre Československo či Družstvo pre predaj bryndze viedli pravidelné rokovania o spôsobe exportu, vel'kosti kontingentov pre jednotlivé podniky ako aj predajnú cenu. Každoročne sa ohl'adne týchto tém konali náročné rokovania.

${ }^{55}$ SNA BA, f. ZB a MP v BB, šk. č. 1, bez sign.
} 
ktoré im umožňovali predávat' so stratou, resp. pod cenu, a tak získat' rozhodujúcu konkurenčnú výhodu. ${ }^{56}$

$\mathrm{V}$ druhej polovici 30. rokov 20. storočia sa vážne diskutovalo o spoločných profesionálnych predajcoch bryndze vo Viedni, ako aj o spoločnom marketingu a propagačnej predajni. Na tento vývojový stupeň však bryndziari nedozreli, tento krok vytrvalo odmietali najmä väčší exportéri. Opätovne otázku spoločného marketingu v roku 1937 predniesol Bryndziarsky syndikát. Požadoval od výrobcov - exportérov 15 až 20 tisíc korún ako účastnícky poplatok na pokrytie výdavkov propagácie na vel'trhu vo Viedni. Hlavnými kritikmi tohto návrhu boli P. Molec a Š. Vagač. Zástupcovia Syndikátu sa nevzdávali svojho zámeru, žiadali aspoň ich vlastné letáky a určité množstvo bryndze na ochutnávku. Tiež žiadali o špeciálne balenie v geletkách s nápisom Slovakischer original Brimsen. ${ }^{57} \mathrm{~K}$ vážnemu ohrozeniu rakúskeho trhu došlo po marci 1938. Hodnotenie exportu po anšluse Rakúska nacistickým Nemeckom ukazovalo rastúcu paniku exportérov z politického vývoja a jeho dopadu na vývoz. ${ }^{58}$

Tab. 5. Porovnanie domácej spotreby bryndze a exportu do Rakúska (t) ${ }^{59}$

\begin{tabular}{|c|c|c|c|c|}
\hline & 1936 & 1937 & 1938 & 1939 \\
\hline $\begin{array}{c}\text { DOMÁCA } \\
\text { SPOTREBA }\end{array}$ & 479 & 550 & 565 & 604 \\
\hline $\begin{array}{c}\text { EXPORT- } \\
\text { RAKÚSKO }\end{array}$ & 347 & 367 & 354 & 414 \\
\hline
\end{tabular}

V zlej situácii sa v rokoch 1918 - 1948 nachádzal aj základný predpoklad syrárstva a bryndziarstva - chov oviec. Od začiatku 20. storočia bol prítomný trvalý trend poklesu počtu chovaných oviec. Vojnové udalosti dvoch svetových konfliktov a s tým súvisiace rozsiahle rekvirovanie viacerých armád, ${ }^{60}$ najmä v rokoch 1944 - 1945, prispeli k rapídnej devastácii počtu oviec a ich chovu. Kým v roku 1911 bolo na území

\footnotetext{
${ }^{56}$ SNA BA, f. ZB a MP v BB, šk. č. 3, bez sign.

${ }^{57}$ SNA BA, f. ZB a MP v BB, šk. č. 3, bez sign.

58 „Po rakúskych udalostiach môžeme tvrdit', že niektoré bryndziarske firmy stratili hlavu a v snahe etablovat'sa na československom trhu stratou rakúskeho predávajú za každú cenu a zapríčiňujú znižovanie cien. Nemožno však situáciu bryndziarstva dnes považovat' za beznádejnú a v tom prípade, ak bude prevedená dobrá organizácia predaja, možno dúfat', že sa ona podstatne zlepší (SNA BA, f. ZB a MP v BB, šk. č. 3, bez sign.).

${ }^{59}$ BALKO, J.: Bryndziarsky priemysel...., s. 45.

60 1. Československá armáda na Slovensku, Wehrmacht, Červená armáda, Rumunská král'ovská armáda.
} 
Slovenska chovaných takmer milión oviec, v roku 1930 to bol len necelý pol milión a v roku 1945 už len 276 tisíc oviec. ${ }^{61}$

Ovca bola pre obyvatel'ov okresu Zvolen, najmä lazníkov, mimoriadne dôležité hospodárske zviera. Poskytovala mlieko ako prvotnú, ale aj druhotnú surovinu, d'alej mäso a vlnu. V rámci okresu vieme vymedzit' dve hlavné oblasti chovu oviec - Podpol'anie a Pliešovskú kotlinu. Rozšírené boli dva druhy plemien - cigajské a valašské.

Ovčiarstvo sa na Podpol'aní datuje už do obdobia 15. - 16. storočia a súvisí najmä s valaskou kolonizáciou. „Chov oviec sa rozšíril najmä od začiatku 18. storočia, ked' boli okolité hory zväčša vyrúbané a získali sa aj pasienky. Ich počet sa odhaduje na 50 - 60 tisíc."62 Podl'a regionálneho mliekarenského odborníka J. Soca „chov oviec bol dovtedy výhodný, dokial' bolo možné vyrobenú bryndzu vyvážat' vo väčšej miere za hranice štátu a dokial' cena vlny bola primerane platená. Zmenšený odbyt ovčieho syra ako aj nízke ceny vlny mali za následok pochopitel'ne zmenšovanie počtu chovu oviec."63

Snaha systematicky a funkčne riešit' tento problém bol prítomná už dlhšiu dobu. Zasadnutie Národohospodárskej župy Stredoslovenskej vo Zvolene v októbri 1933 rokovalo o tejto problematike. Boli vymedzené štyri hlavné problémové oblasti v chove oviec: nízke ceny za kvalitnú vlnu, nízke ceny za mliečne výrobky, redukcia odbytu do Rakúska a Mad'arska, zredukovanie rozlohy pastvín. ${ }^{64}$

Tab. 6. Vývoj počtu oviec v okrese Zvolen a vo vel'kých obciach okresu65

\begin{tabular}{|c|c|c|c|c|}
\hline & 1928 & 1934 & 1936 & 1943 \\
\hline OKRES ZVOLEN & 18685 & 15641 & 17604 & 12227 \\
\hline DETVA & 2416 & 2511 & 2395 & 1818 \\
\hline DOBRÁ NIVA & 739 & 1038 & 418 & 775 \\
\hline HRIŇOVÁ & 850 & 776 & 776 & 1179 \\
\hline OČOVÁ & 895 & 936 & 1028 & 856 \\
\hline PLIEŠOVCE & 5513 & 1204 & 3613 & 2554 \\
\hline
\end{tabular}

Chov oviec bol rozšírený najmä v katastroch vel'kých pol'nohospodárskych obcí okresu - Detva, Dobrá Niva, Hriňová, Očová, Pliešovce a Sása.

\footnotetext{
6125 rokov mliekarenského závodu vo Zvolene 1951 - 1976, s. 54. (brožúra)

62 JANTO, Juraj: Salašný chov oviec v Detve a na Slovensku. In: Muzeológia a kultúrne dedičstvo. roč. 4, č. 2, 2016, s. 99.

${ }^{63}$ SOC, J.: Mlekarstvo na..., s. 78.

64 Obzor, október 1933, III r., č. 10.

65 ŠA BB, p. AZV, f. OÚ vo Zvolene 1923 - 1945, šk. č. 92, 99, 119, 134, 195, 245 adm. 
Celkovo počet oviec klesal, až na krátke obdobie v polovici 30. rokov, ked' ceny za mlieko, mäso a vlnu rástli, a tým sa chov javil ako rentabilný. Medzi najväčších chovatel'ov patrili Vojtech Lassovszký z Detvy, rodina Goldfusová z Ostrej Lúky, Ján Sedliak z Vel'kej Lúky a Štátny vel'kostatok Vígl’aš. ${ }^{66}$

\section{Vojtech Wittmann - vizionár slovenského mliekarenstva}

Vo všeobecnom vedomí verejnosti sa spája bryndziarstvo najmä s rodinami Vagačovcov, Molecovcov či Makovických. No najvýznamnejšie sa do jeho dejín zapísala židovská rodina Wittmannovcov.

Zakladatel'om podniku bol Ignác Wittmann, ktorý sa spolu s rodinou koncom 19. storočia prest’ahoval z Liptova do Zvolena. Svoju prevádzku založil v roku 1891. Systematickou prácou, progresívnymi prístupmi vo výrobe i v predaji, s charakteristickou ctižiadostivost'ou vlastnou židovskému elementu v podnikaní, sa z jeho bryndziarne a syrárne stal koncom 30. rokov 20. storočia najväčší podnik svojho druhu v celom Československu. Jeho význam presahoval stredoeurópsky priestor.

Podnik Ignác Wittmann a syn bol hlavnou súčast'ou Spojených bryndziarní. Všeobecne sa udáva za rozpad podniku rok 1922 alebo 1923. V lete 1924 však vystupoval Ignácov syn Vojtech Wittmann ako samostatný majitel' bryndziarne a syrárne. Dokladá to aj jeho žiadost' o povolenie držby rádioelektrického prijímača ${ }^{67}$ datovaná z leta $1924 .{ }^{68}$ Zároveň táto žiadost' dokladá aj hmotné a finančné postavenie bryndziarskej rodiny, ked'že v roku 1924 bolo vlastníctvo rádia určitou prestížou. Napriek tomu mala výroba wittmannovského podniku určité kvalitatívne deficity. Ešte aj v roku 1927 sa mlieko pri spracovávaní len odstred'ovalo namiesto pasterizácie. Navyše jeho distribúcia a predaj boli len v kanvách, ${ }^{69}$ ktoré neudržali dlho jeho spotrebitel'skú životnost' a nespíňali ani zd'aleka prísne hygienické štandardy. Pri bežnej manipulácii boli aj nepraktické.

Podnik vyrábal mnoho druhov mliečnych výrobkov. Základom bola samozrejme bryndza v jej rôznych druhoch. Ďalej sa v továrni vyrábali tavené syry, syry Iwus, Pustohradský Ďumbier, Bača, Anča, Encián, podl'a J. Soca Salámový syr lisovaný a podl'a A. Vagača Salámový syr lisovaný oštiepkový v údenom stave. Zaujímavým druhom boli Jastrab syry, ktoré sa skladali z Dezertného, Romadúrového a Trojchut'ového syra. V. Wittmann zaviedol výrobu Bella Viera syru. ${ }^{70}$

Široká a pestrá paleta výrobkov wittmannovského podniku predurčovala aj vysoký príjem mlieka od odberatel'ov. Podl'a údajov z roku 1938

\footnotetext{
66 ŠA BB, p. AZV, f. OÚ vo Zvolene 1923 - 1945, šk. č. 134, 4788/1937 adm.

${ }^{67}$ Archaický, dobový názov rádia.

68 ŠA BB, p. AZV, f. OÚ vo Zvolene 1923 - 1945, šk. č. 3, 325/1925 adm.

${ }^{69} 25$ rokov mliekarenského závodu vo Zvolene 1951 - 1976, s. 40. (brožúra)

70 KERESTEŠ, J. - SELECKÝ, J.: Mliekarstvo a syrárstvo..., s. 183.
} 
dodávali denne do podniku nasledovné množstvá mlieka tieto subjekty: rol'níci z Babinej 800 l, z Budče 500 l, z Dobrej Nivy 722 l, z Dúbrav 200 l, z Holcovho Majera 200 l, z Kováčovej 150 l, z Lieskovca 126 l, z Lukavice 280 l, zo Sampora 340 l, z Tŕnia 60 l, z Turovej 200 l, z Vel'kej Lúky 185 l, zo Zolnej 180 l. Mestský statok Zvolen - Bakova jama dodával do Wittmannovskej 100 l. Najväčším dodávatel’om bola Správa štátnych majetkov Vígl'aš. Dvor Očová-Želobudza dodával $1600 \mathrm{l}$ mlieka denne a dvor Kocáň $28001 .{ }^{71}$ Tá istá hospodárska štatistika okrem denného príjmu mlieka na spracovanie ponúka aj údaje o mesačnej výrobe. Wittmannovci vyrobili mesačne „2331 ks syru eidam, 874 ks Salámového syru, 204 ks syru Bella Viera, 680 ks syru Trapist, syru Fromage 385 ks, syru v hrudách 1529 ks, čajového 1821 kg a tabul'ového masla 441 kg, 38 l šl'ahačky a 390 l kyslej smotany." ${ }^{\prime 2}$ Tieto údaje svedčia o jednoznačnom prvenstve v regióne a o významnom postavení z celoštátneho hl'adiska.

V rámci wittmannovského podniku boli dôležité okrem zvolenskej aj dve d’alšie prevádzky - v Babinej a v Sáse. V Babinej sa vyrábal údený salámový syr. V roku 1940 sa tu spracovalo 237 tisíc l mlieka, z ktorého sa vyrobilo $21358 \mathrm{~kg}$ syrov. V Sáse sa vyrábalo popri syroch - zvolenský syr plesňový aj čajové maslo. Celkovo sa tu v roku 1940 spracovalo 420 tisíc l mlieka a vyrobilo $42469 \mathrm{~kg}$ syrov a $2889 \mathrm{~kg}$ masla. $^{73}$

Zakladatel' podniku I. Wittmann zomrel 2. apríla 1936. Jeho úmrtie zachytila aj pamätná kniha mesta: „dnes dokonal vo veku 68 rokov svojho požehnaného života pán Ignác Wittmann, zakladatel' dnes tak široko známej firmy pre bryndziarsky a syrársky priemysel. Mesto naše stratilo v ňom jedného zo svojich popredných občanov. "74 Podnik definitívne prebral V. Wittmann, druhý Ignácov syn Karol sa stal praktickým lekárom vo Zvolene.

Etnicky židovská rodina sa stala po októbri 1938 terčom štátneho teroru a diskriminácie kvôli svojmu pôvodu. V slobodných občianskych podmienkach 1. ČSR si rodina Wittmannovcov vyprofilovala identitu lojálnu k štátnej koncepcii jednotného československého národa. Od židovstva sa rodina odklonila nielen spôsobom občianskeho života, ale aj odklonom od izraelitskej viery. Vojtech ako prívrženec československých vládnych strán a činorodý občan vo Zvolene pozvol'na opustil verejný život po 6. októbri 1938, ked' sa k moci dostali l’udáci. Hospodárske riešenie židovskej otázky sa stalo po 6. októbri poprednou politickou témou. Snahou režimu bolo obmedzenie vplyvu Židov v národnom hospodárstve. Prvú fázu riešenia tejto problematiky predstavoval tzv.

\footnotetext{
71 ŠA BB, p. AZV, f. OÚ vo Zvolene 1923 - 1945, šk. č. 146, 2484/1938 adm.

72 ŠA BB, p. AZV, f. OÚ vo Zvolene 1923 - 1945, šk. č. 146, 2484/1938 adm.

73 ŠA BB, p. AZV, f. OÚ vo Zvolene 1923 - 1945, šk. č. 195, 21733/1941 adm.

${ }^{74}$ Lesnícke a drevárske múzeum vo Zvolene, Pamätná kniha mesta Zvolen 1934 - 1945, s. 63.
} 
Sidorov komitét. Praktické riešenie návrhov vypracovaných Sidorovým komitétom odsunuli marcové udalosti 1939, vznik samostatného štátu a následná konsolidácia. Opätovným stimulom úpravy hospodárskeho života Židov v 1. SR bol začínajúci súboj medzi dvoma krídlami HSL'S. Kým radikáli chceli rýchlym a razantným spôsobom odstránit’ židovský ekonomický vplyv, pragmatickejší a opatrnejší umiernení chceli zmeny zavádzat' postupne bez negatívnych dopadov na národné hospodárstvo. Protižidovská politika kulminovala v 1. SR v rokoch 1941 - 1942. Prvou vážnou protižidovskou perzekúciou, ktorá zasiahla rodinu V. Wittmanna, bola diskriminácia v bytovej otázke. V roku 1941 prišli najmä zámožní Židia o svoje luxusné domy a byty. Viacerí z nich však vd'aka konexiám $\mathrm{z}$ čias 1. ČSR obchádzali diskriminačné nariadenia. Dôkazom toho je aj fakt, že Ústredňa štátnej bezpečnosti kontaktovala listom z 10. júla 1942 Štátny policajný úrad vo Zvolene s výčitkou, prečo ešte bývalý židovský bryndziar býva vo svojom luxusnom byte na Námestí Andreja Hlinku. Zvolenské úradné miesta sa ho zastali, pretože na základe uznesenia mestskej rady a súhlasu miestnej organizácie HSL'S mohol nad'alej bývat' vo vyčlenených častiach svojho pôvodného domu. ${ }^{75}$

V rámci procesu arizácie bola Bryndziareň a syráreň Wittmanovcov hodnotným podnikom určeným pre nového nežidovského majitela. Záujemcov o výnosný a moderný mliekarenský závod bolo mnoho, no najúspešnejší sa ukázal tajomník HSL’S v Bratislave Teofil Babala. Ten sa rozhodnutím Ústredného hospodárskeho úradu z 12. augusta 1941 stal novým majitel'om, pričom Vojtecha ako odborníka si v podniku ponechal. Podl'a hospodárskych dokumentov bol T. Babala majitel'om podniku len dva roky: „Prenajímatel' sa v prípise z 28. augusta 1943 zriekol prevádzky podniku, resp. správy. “76 Živnost' mu bola oficiálne zrušená až v roku 1949. Novým majitel'om lukratívnej továrne sa stal po T. Babalovi Zväz mliekarenských družstiev.77 S vysokou pravdepodobnost'ou práve vd'aka vzdelaniu, odbornosti, bohatstvu a kontaktom na vplyvných l'udí sa podarilo členom rodiny Wittmannovcov vyhnút' deportáciám do nemeckých lágrov. Primárnou záchranou Židov pred deportáciami boli pracovné legitimácie, rezortné alebo prezidentské výnimky. Bývalý továrnik $\mathrm{V}$. Wittmann, ktorý patril do kategórie nenahraditel'ných odborníkov sa stal držitel'om najcennejšieho ochranného dokumentu, a to prezidentskej výnimky. Jednotlivé žiadosti sekretariát prezidenta J. Tisu pred vynesením rozhodnutia preveroval. Zvolenské úrady sa postavili k žiadosti $\mathrm{V}$. Wittmanna kladne: „V. Wittmann je prvotriedny odborník v hospodárskom odvetví s bryndzou. Svojho času bol aj predsedom Živnostenského spoločen-

\footnotetext{
75 ŠA BB, p. Banská Bystrica, fond: ŠPÚ vo Zvolene 1940 - 1942, šk. č. 12, 1502/1941 adm.

76 ŠA BB, p. AZV, f. OÚ vo Zvolene 1923 - 1945, šk. č. 220, E-9111/4-6/10/1943 adm.

77 ŠA BB, p. AZV, f. OÚ vo Zvolene 1923 - 1945, šk. č. 220, E-9111/4-6/10/1943 adm.
} 
stva vo Zvolene. "78 Dôležitým faktom udelenia výnimky pre žiadatel'a bolo aj to, že jeho manželka Mária, dcéra generála Šnejdárka, mala v zmysle rasových zákonov árijský pôvod. Podpornú úlohu hral fakt, že V. Wittmann na rôzne verejné zbierky venoval značnú sumu peňazí - napr. na zlatý poklad štátu, hospodársku pôžičku na obrodu štátu či na stranícku charitu Zimná pomoc. ${ }^{79}$ Aktívne a štedro podporoval aj l'udácke organizácie - HG a HM. ${ }^{80} \mathrm{Z}$ hl'adiska V. Wittmanna však išlo skôr o snahu vyhoviet' režimu a získat' si plusové body, než o podporu z presvedčenia. Napriek t’ažkému l'udskému údelu V. Wittmann svoj vol'ný čas a nútené vyradenie zo spoločenského a hospodárskeho života využil plodne. Nezaprel tým činorodú povahu typickú pre jeho osobnost'. V lete 1944 vydal svoje životné odborné dielo - Smernice pre budúci vývoj slovenského mliekarenstva. Podl'a jeho vlastných slov: „stručne uvádzam smernice a úlohy, ktoré vyžaduje mliekarstvo terajšej doby so zvláštnym zretel'om na naše pomery. Osobne už dávno verím vo vel'kú budúcnost' a poslanie slovenského mliekarstva. Táto moja viera zosilnila sa hlavne za terajšej svetovej vojny, ked' tento spis zhotovujem, v predvečer dejinných reforiem št'astnejšej budúcnosti. Vel'kým nedostatkom tohto spisu je, že vo svojich štatistických údajoch obmedzujem sa len na územie pomníchovského Slovenska. Pre nedostatok štatistického materiálu a z iných príćin tejto vojnovej doby nebolo mi to inak možné..."81 Úvodné slová autora vystihujú jeho zanietenost' pre mliekarenský odbor, napriek nel'ahkej osobnej, rodinnej a spoločenskopolitickej situácii. Zretel'né sú aj očakávania vel'kých zmien a nádej v št'astnejšiu budúcnost'. Autor sebareflexívne popisuje aj limity svojho elaborátu, čo je v rovine publikačnej etiky samozrejmé. Zároveň čitatel'ovi ponúka svoje smelé plány do budúcnosti s náčrtom všeobecného budovania slovenského mliekarenstva po vojne.

Štruktúra Wittmannovej odbornej štúdie je logická a zahrňuje základné oblasti a okruhy skúmanej témy. Delí sa na tri časti: prvá má rovnomenný názov práce, druhou je Organizačný plán pre budúcnost' slovenského mliekarstva a tret'ou Náčrt definície účelu mliekarenského podnikania. Významným faktom štúdie je, že sa nezameriava len na lokálne pomery, t. j. územie okresu Zvolen, ale popisuje mliekarenstvo a jeho aktuálny stav, rozhodujúce činitele a možnosti rozvoja v rámci celého územia 1 . SR v rokoch 1939 - 1945. V prvej časti štúdie logicky a

\footnotetext{
${ }_{78}$ ŠA BB, p. AZV, f. OÚ vo Zvolene 1923 - 1945, šk. č, 87, 391/1943 prez.

${ }^{79}$ Pravdepodobne z oportunistických dôvodov.

${ }^{80} \mathrm{Na}$ zimnú pomoc venoval celkovo 36-tisíc korún, pre HG a HM 5-tisíc korún, pre nezamestnaných 10-tisíc korún. Na hospodársku obrodu slovenského štátu upísal 30-tisíc korún. Tieto sumy boli na danú dobu mimoriadne vysoké.

81 WITTMANN, Vojtech: Smernice pre budúci vývoj slovenského mliekarenstva. Zvolen : 1944, s. 2.
} 
súhrnne charakterizuje všetky rozhodujúce činitele mliekarenstva na Slovensku, vychádzajúce z podrobnej fyzicko-geografickej analýzy. Podl’a jeho názoru sú prírodné predpoklady na území Slovenska pre mliekarstvo priaznivé, vd’aka miernemu podnebnému pásmu s dostatočnými zrážkami, vhodnými pôdami a rozšíreným podhorským a horským pásmom vhodným pre pasienkový chov, najmä ovčiarstvo. ${ }^{82}$ Celkovo hodnotí segment mliekarstva tak, že „má plné životné oprávnenie, pretože sú tu výhodné prírodné a hospodárske podmienky. Zemedelský l'ud je obzvlášt' súci pre rozvoj mliekarstva, sú dané predpoklady miernych výrobných nákladov, akost' mlieka a klimatické podmienky zaručujú vel'mi hodnotnú výrobu a odbyt s primeraným speňažením môže byt' zaistený v rámci organizovaného usmernenia na vel'a rokov napred, bez vel'kých t'ažkostí." ${ }^{33}$ Základné tézy jeho úvah o budúcom vývoji mliekarenstva oscilujú pri týchto témach: výrobných nákladoch, syrárstve, ktoré považuje za základný fundament speňažovania $v$ rámci spracovávania mlieka, modernizácie a systematizácie celej mliekarskej výroby, budovania mliekarenského odborného školstva a výskumu, obchodu, distribúcie a propagácie. Podl'a jeho slov „môžeme sistotou tvrdit', že slovenské mliekarské výrobky rovnajú sa akost’ou zahraničným výrobkom, pretože naše mlieko pochádza zväčša s horských pasienok. Dobrá výroba je dnes skôr otázka technická a vedecká, a máme teraz už aj dôkazy, že slovenské mliečne výrobky pokladajú aj $v$ cudzine za prvotriedne." ${ }^{84}$ Zásadným spôsobom porovnáva V. Wittmann stav slovenského mliekarenstva s vyspelými štátmi a ich mliekarenským sektorom potravinárskeho priemyslu, samozrejme, prihliadnuc na vojnové pomery. Komparácia je zameraná hlavne na štáty s rozvinutou a modernou živočíšnou výrobou - Dánsko, Holandsko a Švajčiarsko.

Tab. 7. Štatistické porovnávanie vybraných ukazovatel’ov v štúdii V. Wittmanna ${ }^{85}$

\begin{tabular}{|c|c|c|c|}
\hline \multirow{2}{*}{$\begin{array}{l}\text { PRODUKCIA } \\
\text { MLIEKA NA } \\
1 \text { OBYV. (l) }\end{array}$} & SLOVENSKO & DÁNSKO & ŠVAJČIARSKO \\
\hline & 203 & 1454 & 667 \\
\hline \multirow{2}{*}{$\begin{array}{c}\text { ROČNÝ } \\
\text { PRIEMER } \\
\text { PRODUKCIE } \\
\text { 1 DOJNICE (l) }\end{array}$} & SLOVENSKO & DÁNSKO & HOLANDSKO \\
\hline & 1300 & 3100 & 3500 \\
\hline
\end{tabular}

\footnotetext{
82 WITTMANN, V.: Smernice pre..., s. 7.

83 WITTMANN, V.: Smernice pre..., s. 13.

${ }^{84}$ WITTMANN, V.: Smernice pre..., s. 13.

85 WITTMANN, V.: Smernice pre..., s. 15.
} 
Uvedené údaje vidí V. Wittmann v dvoch rovinách: „počet dojníc je na Slovensku primalý, dojivost' kráv nie je primeraná daným podmienkam. V našej zemi produkované mlieko nie je dosial' ekonomicky zachytené a mliekarstvo vôbec predstavuje v hospodárskom organizme nášho štátu len celkom podradného činitel'a."86 Vo svojich myšlienkach d'alej analyzuje negatíva súčasného stavu, ked' opät' poukazuje na malý počet dojníc, nevyužívanie jestvujúcich možností v plnej miere, ako aj nehospodárnu výrobu. Verí, že oproti výrobe masla a distribúcii konzervovaného mlieka môže pozdvihnút' celé mliekarstvo výroba syrov so špeciálnym miestom pre výrobu slovenskej osobitosti - bryndze.

Autor nehodnotí len minulost' a vtedajší aktuálny stav, ale podáva aj jednotlivé návrhy na zlepšenie situácie. Vel'ký dôraz kladie na pôdu, krmoviny, scel'ovanie pasienkových pôd. „Súhrnne môžeme povedat', že prvým rozhodujúcim úkolom mliekarského plánovania má byt' obozretná starostlivost'o pôdu, určenú pre pestovanie krmovín, opatrenie lúk a pasienok, ciel'avedomé pestovanie krmiva, priemyselná výroba krmív, prípadne obstarávanie týchto $v$ cudzine." ${ }^{\circ 7} \mathrm{~V}$ nadväznosti na pôdu a krmivá venuje pozornost' chovu dobytka, kde pokladá za životne dôležité chovat' odolné a výkonné plemená. Nezabúda však na dôležitost' opatery a udržiavania dobrého zdravotného stavu chovného dobytka. Nevyhnutným predpokladom týchto činností sú podl'a V. Wittmanna školenia pre gazdov a budovanie odborného školstva. ${ }^{88}$ Dôležitý tlak na odborné pracovné sily vytvára aj trend vel'kovýroby, preto „na mliekarenský personál sa dnes kladú mnohostranné požiadavky, a preto treba rátat's tým, že kandidáti musia preukázat' vyhovujúce vyššie školské vzdelanie. V mnohých štátoch sa to predpisuje už i zákonom." ${ }^{89}$ Popri školstve má fungovat' aj veda a výskum, čo je významne pokroková myšlienka na čas vzniku jeho odborného diela. Autor však nezabúda ani na odberatel'ské faktory ako obchod, distribúciu a propagáciu mliečnych výrobkov.

V. Wittmann bol pre svoj pôvod od počiatku 1. SR rasovo prenasledovaný, čo predurčovalo jeho spoluprácu s odbojom. Koncom roku 1943 sa stal za občiansky odboj spolu s bývalým zvolenským starostom, sociálnym demokratom Danielom Ertlom a komunistickým predákom Rudolfom Blažovským, členom predsedníctva ilegálneho Okresného národného výboru. Po vypuknutí SNP v auguste 1944 sa Vojtech ${ }^{90}$ spolu s bratom Karolom aktívne zapojil do verejného života na povstaleckom území. 0 to t'ažšie chvíle ich čakali po potlačení SNP. Miestne nemecké

\footnotetext{
86 WITTMANN, V.: Smernice pre..., s. $16-17$.

87 WITTMANN, V.: Smernice pre..., s. 24.

88 WITTMANN, V.: Smernice pre..., s. 27.

89 WITTMANN, V.: Smernice pre..., s. 31.

${ }^{90}$ Vojtech bol lídrom občianskeho odboja vo Zvolene od leta 1943.
} 
orgány sa spoliehali hlavne na anonymných udavačov. Na ich úkryt upozornil velitel'stvo HG vo Zvolene list neznámeho autora: „,Velitel'stvu HG vo Zvolene! Pokladám za svoju povinnost' oznámit' vám, že l'udia ktorí organizovali puč vo Zvolene sa tu skrývajú. To sú: Dr. Wittmann a jeho brat Béla Wittmann, bryndziar. Mali sme možnost' pozorovat', že celé zatýkanie sa viedlo za puču z Wittmannovej bryndziarne a že na čele stál práve bryndziar Wittmann a druhý Dr. Wittmann prepožičal svoj dom vol'ákemu súdu Povstalcov, kde sa schádzali poprední činitelia povstaleckí a súdili uvedomelých Slovákov. Títo l'udia sú ešte tu!!! A neuveritel'né, že ich ukrývajú l'udia, o ktorých si myslíte, že sú praví Slováci - skrývajú ich Finkovci! Nachádzajú sa u Finku v kúte vtáčiara Dr. Eleméra Finku pri hnojisku, majú spravený bunker. Zaiste sa postaráte o to, aby sa títo l'udkovia dostali ta, kde právom patria!!! Na stráž, spolupracovník." tvrdenie potvrdzuje aj Vojtechov brat Karol. „Po povstaní som utekal do hôr aj s bratom Vojtechom na Pol'anu a potom až do 14. decembra 1944 sme sa schovávali po dedinách vokolí Očovej. Bol to Zoltán Finka, ktorý nás schoval v záhrade svojho brata dr. Eleméra Finku v jednom domčeku, kde mal zoologickú92 záhradu. "93 0 oboch sa staral, navštevoval ich v úkryte, nosil im teplú stravu a lieky. Je obdivuhodné, že po životných útrapách, ktoré V. Wittmann prežil počas 1 . SR, nad'alej ostal žit' vo Zvolene ${ }^{94}$ a plánoval sa vrátit' k podnikaniu v mliekarenstve. Nebola to len snaha obnovit' činnost' v medziach spred roku 1938. Bryndziarsky vizionár pripravoval dynamický progres podniku. Jeho firme schválilo MNV vo Zvolene znovuobnovenie živností 17. júna 1947. Išlo o živnost' na prevádzanie živnostenskej výroby bryndze a syra, živnost' mliekarenstva, ošetrovania a spracovávania mlieka na rôzne mliečne výrobky, živnost' na odstred'ovanie mlieka a mliečnu výrobu. Vo vyhovení žiadosti pre V. Wittmanna sa zdôrazňuje, že „nejde o novozriadenú živnost', lež o obnovenú, pretože pôvodná bola na základe rasových zákonov zlikvidovaná."95 Už 8. augusta 1946 podal V. Wittmann na zasadnutie $\mathrm{MNV}$ vo Zvolene návrh na odpredaj pozemku starého cintorína pre výstavbu nového moderného mliekarenského podniku. Išlo o pozemok Zvolenského cintorínového fondu evanjelického a katolíckeho z roku 1780. Ukončenie pochovávania na tomto cintoríne bolo rozhodnutím úradov datované na 1 . augusta 1877 a od 12 . marca 1934 výmerom Okresného úradu vo Zvolene bolo povolené na tomto území zriad'ovanie stavieb. Žiadost' V. Wittmanna nebola prero-

\footnotetext{
91 ŠA BB, p. ABB, f. OL'S vo Zvolene, T 54/46.

${ }^{2}$ Presnejšie ornitologickú.

${ }_{93}$ ŠA BB, p. ABB, f. L'S v Banskej Bystrici, 1945 - 1948, 1/48.

${ }^{94}$ Bol aktívny aj v orgánoch MNV a ONV. Sympatizoval s Demokratickou stranou.

95 ŠA BB, p. AZV, f. MNV vo Zvolene 1944 - 1977 (nespracovaný fond).
} 
kovaná kvôli nedostatku členov MNV na zasadnutí. Opätovne bola žiadost' prerokovaná o štyri dni neskôr na pokračujúcom zasadnutí. Všetci členovia jednohlasne odsúhlasili predaj pozemku, pričom za $1 \mathrm{~m}^{2}$ bola určená cena 150 Kčs. V zápisnici z rokovania sa ohl'adne plánovanej investície písalo: „Vojtech Wittmann, továrnik vo Zvolene mieni vybudovat' vo Zvolene nový mliekarenský podnik, ktorý by vyhovoval technicky, hygienicky a ekonomicky podmienkam dnešnej modernej doby, nakol'ko terajší podnik na mieste kde sa nachádza, nemôže byt' rozširovaný a zmodernizovaný. Kupujúci je povinný z vlastných prostriedkov postavit' nový moderný mliekarenský podnik podl'a predložených plánov. So stavbou nového mliekarenského podniku kupujúci je povinný započat' najpozdejšie do 31. decembra 1947."96

V. Wittmann zaplatil za pozemok pre nový podnik o rozlohe 3090 $\mathrm{m}^{2} 463$ tisíc Kčs. Peniaze na kúpu pozemku pochádzali z dvoch zdrojov: z jeho vlastných financií a z pôžičky, ktorú mu poskytla Mestská sporitel'na. ${ }^{97} \mathrm{~V}$ roku 1947 mu bola schválená komerčná pôžička vo výške 15 miliónov na výstavbu nového a moderného objektu mliekarne - bryndziarne - taviarne syrov. ${ }^{98}$ Podl'a zápisnice $\mathrm{ONV}$ vo Zvolene 7,5 milióna korún tvorili vlastné Wittmannove prostriedky a komerčná pôžička z Tatra banky. Druhú polovicu vo výške 7,5 milióna korún mala tvorit' bezúročná štátna pôžička. ${ }^{99}$

10. októbra 1947 prerokovávali členovia MNV vo Zvolene žiadost' spoločnosti I. Wittmann a syn o predĺženie kanalizácie z okraja mesta do novej stavebnej zóny, t. j. Štefánikovej ulice. Podl'a viacerých rozpočtových podkladov mala táto investičná akcia stát' od 70 do 100 tisíc Kčs. MNV vo Zvolene podporoval túto investíciu, avšak nemal dostatočné prostriedky na realizáciu. Preto sa uznieslo, že pokým bude vybavený úver v banke, potrebné finančné prostriedky mestu Zvolen požičia sama firma I. Wittmann a syn. Jedným z dôvodov bolo aj časové hl'adisko, pretože výstavba samotného podniku intenzívne pokračovala a keby mesto nepreviedlo v zime 1947 - 1948 potrebné práce na novej kanalizácii, tak by podnik nemohol začat' fungovat'.100 Výstavba podniku sa oficiálne začala 15. augusta 1947.101 Práce na stavbe pokračovali rýchlo a už 11. novembra 1947 boli dokončené základy nového podniku. V. Wittmann ako lokálpatriot oslávil túto skutočnost' naozaj filantropicky. Zo svojich financií venoval 20 tisíc Kčs mestu Zvolen na sociálne

\footnotetext{
96 ŠA BB, p. AZV, f. MNV vo Zvolene 1944 - 1977 (nespracovaný fond).

97 ŠA BB, p. AZV, f. MNV vo Zvolene 1944 - 1977 (nespracovaný fond).

9825 rokov mliekarenského závodu vo Zvolene 1951 - 1976, s. 50. (brožúra)

99 ŠA BB, p. AZV, f. MNV vo Zvolene 1944 - 1977 (nespracovaný fond).

100 ŠA BB, p. AZV, f. MNV vo Zvolene 1944 - 1977 (nespracovaný fond).

101 ŠA BB, p. AZV, f. ONV vo Zvolene 1945 - 1990 (nespracovaný fond).
} 
a reprezentačné účely a 10 tisíc Kčs pre účely Národohospodárskej komisie pod vedením radcu Kolomana Pet'ka. ${ }^{102}$

Povojnové obdobie bolo špecifické rozvojom regionálneho hospodárstva. Člen rady ONV vo Zvolene K. Pet'ko na prvom zasadnutí ONV 8. januára 1948 k tomu poznamenal nasledovné: „sú priaznivé náznaky, že zvolenský okres nastúpil novú cestu všestranného hospodárskeho a kultúrneho rozmachu. Vo Zvolene je v práci výstavba mohutného drevokombinátu Bučina na mechanické a chemické spracovanie dreva, jedinečný to podnik v celej Európe. Buduje sa tiež vel'komliekareň a továreň na mliečne výrobky firmy I. Wittmann a syn, ktorá buduje najmodernejší a najdokonalejší podnik svojho druhu na Slovensku." ${ }^{103}$ Vo februári 1948 však bola výstavba celého mliekarenského závodu ohrozená. Povereníctvo výživy, ktoré poskytlo V. Wittmannovi bezúročnú pôžičku 7,5 milióna korún nedodržalo svoj záväzok. ONV vo Zvolene vyzýval kompetentné orgány bezodkladne poskytnút' firme peniaze na stavbu podniku v zmysle uznesenia Zboru povereníkov z 19. decembra 1947. Vo svojej protestnej nóte tvrdil, že „finančné prostriedky menovanej firmy sú úplne vyčerpané, nie je možné pokračovat' $v$ stavebných prácach, v zaist'ovaní stavebného materiálu na rok 1948 a nie je možné pokračovat' ani vo výrobnej činnosti terajšieho podniku, čím je ohrozená aj zásobovacia situácia obyvatel'stva mliekom a mliečnymi výrobkami." ${ }^{104}$ Kým v rokoch 1938 - 1945 trpel V. Wittmann a jeho rodina kvôli rasistickej ideológii, po komunistickom prevrate vo februári 1948 bol problémom jeho triedny pôvod, teda príslušnost' ku podnikatel'skej vrstve spoločnosti. Vo februári 1949 sa rozhodol emigrovat' do zahraničia. 0 tomto jeho počine sa zmieňuje aj zápisnica MNV vo Zvolene. List V. Wittmanna závodnej rade oznamuje „že okolnosti, ktoré sú vylíčené v jeho liste písanom závodnej rade podniku pohli ho $k$ zúfalému rozhodnutiu opustit' Zvolen."105 Jeho hnutel'ný a nehnutel'ný majetok bol zabavený. Nový mliekarenský podnik, ktorý budoval z posledných fyzických, psychických a finančných síl sa stal základom socialistického mliekarského koncernu - Štátneho podniku Banskobystrické, resp. Stredoslovenské mliekarne.

\section{Okres Zvolen v kontexte slovenského bryndziarstva a syrárstva}

Predložená štúdia sa pokúša o popis základných čŕt vývoja bryndziarstva a syrárstva v období rokov 1918 - 1948 nielen z celoslovenskej perspektívy, ale aj s dôrazom na región, ktorý patril k jadru uvedeného seg-

102 ŠA BB, p. AZV, f. MNV vo Zvolene 1944 - 1977 (nespracovaný fond). 103 ŠA BB, p. AZV, f. ONV vo Zvolene 1945 - 1990 (nespracovaný fond). ${ }_{104}$ ŠA BB, p. AZV, f. ONV vo Zvolene 1945 - 1990 (nespracovaný fond). 105 ŠA BB, p. AZV, f. MNV vo Zvolene 1944 - 1977 (nespracovaný fond). 
mentu národného hospodárstva. V žiadnom prípade si však nenárokuje na absolutórium poznatkov, ktoré sú limitované dostupnými pramennými zdrojmi ako aj limitmi dosial' málo skúseného mladého autora.

Bryndza je slovenským potravinárskym fenoménom. Jej výroba a predaj sa stali jedným z nosných prvkov slovenského potravinárstva. Podpol'anie, Pliešovská kotlina a stredné Pohronie - mikroregióny okresu Zvolen sa pre svoj geografický a sociálny charakter stali predurčenými lokalitami pre rozvoj bryndziarstva a syrárstva. Tento fakt potvrdzujú aj mnohé pramenné materiály, predovšetkým o podiele výroby, o nových postupoch pri spracovaní, angažovanosti sa v stavovských organizáciách atd'. Segment bryndziarstva výrazným spôsobom ovplyvnilo niekol'ko významných mužov. Prvenstvo nepochybne patrí Jánovi Vagačovi, ktorý v Detve v roku 1787 postavil a sprevádzkoval manufaktúrnu výrobňu bryndze. V 19. storočí začal proces profesionalizácie výroby zvolenský továrnik Teodor Wallo. S jeho kvalitatívnymi pokusmi dosiahla výroba bryndze novú úroveň. Zároveň inicioval dôležitý zápas o kvalitu bryndze, ktorý prebiehal nasledujúce desat'ročia. Medzníkom, ktorý ovplyvnil bryndziarstvo, bolo vypuknutie 1 . svetovej vojny a rozpad monarchie $v$ roku 1918 . Vojnové pomery síce zaručili odbyt suroviny pre vojsko, no v časoch prajných pre rôzne špekulácie sa kvalitatívny stav výroby výrazne prepadol, a to najmä vinou ziskuchtivých jedincov. Ako obranný mechanizmus tu prvýkrát vidíme kartelizáciu a centralizáciu spracovania bryndze u renomovaných výrobcov. Výsledkom bolo zriadenie Hornouhorských spojených bryndziarní Zvolen. Koniec vojny priniesol rozpad Rakúsko-Uhorskej monarchie na nástupnícke štáty, čím sa medzi stáročnými obchodnými väzbami vytvorili colné bariéry. Klúčcový rakúsky, lepšie povedané viedenský, trh sa stal pre slovenských a zvlášt' regionálnych bryndziarov t’ažko dostupný. Ekonomické výsledky navyše zhoršili zásadné hospodárske krízy medzivojnového obdobia. Podobne ako počas vojny, aj v tomto ohrození sa bryndziari stmel'ovali. Nezvolili však postup jedného zastrešujúceho podniku garantujúceho kvalitu a podmienky predaja, ale založenie stavovských organizácií. Ich úlohou bolo hájit’ na poli legislatívnom aj hospodárskom špecifické záujmy bryndziarov a syrárov. Výsledkom tejto činnosti bol vznik Bryndziarskeho syndikátu, Zväzu pre bryndziarsky a syrársky priemysel a Družstva pre predaj bryndze. Vo všetkých ustanovizniach mali výrobcovia z okresu Zvolen dominantné postavenie.

Krátke obdobie 1. SR zasiahlo do chodu bryndziarstva najmä rasovou perzekúciou židovských bryndziarov, ktorých podiel na trhu bol významný. Vo Zvolene bol pod vplyvom tejto politiky arizovaný Wittmannov podnik. Menšie bryndziarne G. Blüha či K. Ippera boli zlikvidované. Celá hospodárska politika sa musela prispôsobit' nemeckým 
požiadavkám s ohl'adom na vojnovú výrobu a podmienky. Aj preto sa d'alší progres bryndziarstva a syrárstva v tomto období zastavil. Povojnové obdobie prinieslo elán a chut' rozvíjat' dosial' dosiahnuté výsledky a odstránit' vojnové škody. V tomto ovzduší začal V. Wittmann budovat' najväčší moderný mliekarenský podnik v Československu. Zmenou spoločensko-politických pomerov v Československu po roku 1948 prešiel radikálnou zmenou aj celý výrobno-vzt'ahový proces bryndziarstva a syrárstva. Typické rodinné podniky s dlhoročnou tradíciou, špecifickost'ou výroby ako aj garanciou kvality v centrálne riadnom hospodárstve l'udovej demokracie už nemali miesto. Rodinné podnikanie v bryndziarstve a syrárstve prežilo hospodárske krízy či vojny, no s radikálnym politicko-ekonomickým zásahom sa už nevedelo a nemohlo vyrovnat'. Zmeny po roku 1948 teda znamenali koniec pre vyše 150-ročné úspešné rodinné podnikanie Vagačovcov a Molecovcov, ale aj d'alších súkromných výrobcov v okrese Zvolen. 